\title{
MG2809乳酸菌の摂取が大学ラグビー選手の口腔内免疫能に及ぼす影響
}

\author{
花岡 裕吉 ${ }^{1}$, 清水 和弘 ${ }^{2}$, 熟谷 浩輔 ${ }^{1}$, 田村 明 $^{3}$, 竹村 雅裕 ${ }^{1}$, \\ 古川 拓生 ${ }^{1}$, 宮本 俊和 ${ }^{1}$, 渡部 厚一 $^{1}$, 赤間 高雄 $^{4}$

\section{The effects of Lactobacillus gasseri OLL2809 intake on oral immune function in college rugby athletes}

\author{
Yukichi Hanaoka ${ }^{1}$, Kazuhiro Shimizu ${ }^{2}$, Kosuke Washiya ${ }^{1}$, Akira Tamura ${ }^{3}$, Masahiro Takemura ${ }^{1}$, \\ Takuo Furukawa ${ }^{1}$, Toshikazu Miyamoto ${ }^{1}$, Koichi Watanabe ${ }^{1}$ and Takao Akama ${ }^{4}$
}

\begin{abstract}
1 筑波大学大学院人間総合科学研究科, ₹305-8574 茨城県つくば市天王台 1-1-1 (Graduate School of Comprehensive Human Sciences, University of Tsukuba, 1-1-1 Tennoudai, Tsukuba, Ibaraki 305-8574, Japan)

2 国立スポーツ科学センタースポーツ科学研究部， † 115-0056 東京都北区西が丘3-15-1 (Department of Sports Sciences, Japan Institute of Sports Sciences, 3-15-1 Nishigaoka, kita-ku, Tokyo 115-0056, Japan)

3 株式会社明治食機能科学研究所乳酸菌研究部, ₹250-0862 神奈川県小田原市成田540 (Lactic Acid Bacteria Research Department, Food Science Research Laboratories, Meiji Co., Itd, 540 Naruda, Odawara, Kanagawa 250-0862, Japan)

${ }^{4}$ 早稲田大学スポーツ科学学術院，７359-1192 埼玉県所沢市三ケ島 2-579-15 (Faculty of Sport Sciences, Waseda University, 2-579-15 Mikajima, Tokorozawa, Saitama 359-1192, Japan)
\end{abstract}

Received: December 26, 2014 / Accepted: April 17, 2015

\begin{abstract}
The purpose of this study was to investigate the effects of Lactobacillus gasseri OLL2809 (MG2809) intake on salivary secretory immunoglobulin A (SIgA) secretion and incidence of upper-respiratory tract infection (URTI) symptoms among college rugby athletes. Sixty-seven subjects were assigned to a MG2809 group $(n=33)$ or a placebo group $(n=34)$ using a double-blind procedure. Each subject took MG2809 or placebo tablets for 9 weeks. Resting saliva samples were collected before ( 0 week) and after 2, 4, 6, 8, and 9 weeks of the MG2809 intakes. A log of URTI symptoms was kept every day during the study period. Our results showed that salivary SIgA level was significantly increased at 6 weeks in the MG2809 group $(\mathrm{p}<0.05)$, although the placebo group did not show significant change. The duration of URTI symptoms episode in the MG2809 group was significantly shorter than that in the placebo ( $p<$ 0.05). These results suggest that regular intake of MG2809 may enhance oral immune function mediated by SIgA and reduce the risk of URTI in athletes.
\end{abstract}

Jpn J Phys Fitness Sports Med, 64(3): 315-322 (2015)

Keywords : lactic acid bacteria, MG2809, exercise, secretory immunoglobulin A, athlete

\section{緒言}

上気道感染症（感冒）は，アスリート個人の体調や競 技力を著しく低下させるだけでなく, チームに蔓延し, チーム全体の競技力低下にもつながる注視すべき疾患で ある。実際，オリンピックの様な重要な国際大会期間中 にもかかわらず，多くのアスリートが感冒に罹患してい ることが報告されている1). 従って, 感冒の予防は, アス リートの良好なコンディション維持の観点において重要 な課題である。

唾液中の分泌型免疫グロブリンA（Secretory Immunoglobulin A: SIgA）は, 口腔内免疫能の主体であり, 病 原体由来の毒素の中和㧍よび病原体の運動能，増殖能お
よび付着能を阻害することで粘膜下への侵入を防ぐ。ま た，唾液SIgA は一過性の高強度運動により一時的に低 下し ${ }^{2,3)}$, さらに高強度運動の継続により安静時レベルの 低下 ${ }^{4,5)}$ とともに感冒の発症が認められている ${ }^{6)}$. 従って, SIgAの低下を抑制することや，あらかじめSIgAを高め ておくことが感冒の予防に貢献すると予想される。

近年, 乳酸菌の摂取で感冒の予防や症状軽減を試みた 研究がなされている7,8)，継続的な乳酸菌（Lactobacillus plantarum ONRICb0240株）の摂取で健康な高齢者や 成人女性の唾液 $\mathrm{SIgA}$ 分泌が高まることが報告されてい $る^{9,10)}$ ．唾液SIgAの運動応答に対する乳酸菌の効果に ついては, Shimizu et al. ${ }^{11}$ が, 高齢者に扔ける乳酸菌 (Lactobacillus pentosus strain b240株) 摂取が中等度卜 
レーニングによるSIgA 分泌の充進を増強させると報告 している，乳酸菌の摂取がアスリートの唾液SIgAに及 ぼす影響を検討した研究は 2 例しかない. Cox et al. ${ }^{12)}$ は, 陸上中長距離選手に打ける 4 週間の乳酸菌含有カプセ ル (Lactobacillus fermentum VRI-003) の摂取で唾液 SIgA に有意な変動はみられなかったが, 感冒症状の罹 患数捛よび出現日数が減少したことを報告している。し かし，摂取期間が短いことから SIgAへの影響が充分に 検討されていない可能性があることや, クロスオーバー 法を用いたことで乳酸菌とプラセボの効果測定の時期が 2 ケ月ずれており，季節変動 ${ }^{13)}$ やトレーニング状況の違 いが結果に影響した可能性がある. Gleeson et al. ${ }^{14)}$ は, 運動習慣のある成人男女に抒いて16週間の乳酸菌飲料 (Lactobacillus casei Shirota株) でトレーニングによる 唾液SIgA濃度の低下抑制と感冒症状の出現日数の短縮 を報告している。しかし，対象者の性別掞よび年齢（18 -55歳), 競技のレベル (スポーツ愛好家から代表選手 を含む) や種目 (陸上や競泳, 自転車, ラケットスポー ツなど）が統一されていないことから, 性ホルモンの影 響15)やトレーニング状況（運動強度や頻度, 試合や遠征 の有無やスケジュールなど）の違いが測定結果に影響し た可能性がある.さらに, Gleeson et al. ${ }^{14)}$ の研究では, 乳酸菌飲料を遠征先に持参できず，摂取ができなかった 事例が報告されている。これらのことより，対象の競技 や運動環境, 測定時期, 性別, 年齢を統一させ, 測定条 件抢よび摂取条件を整備した形で検討することが，アス リートに打ける乳酸菌の摂取が唾液 SIgA および感冒に 及ぼす効果をより正確に示すために必要である。

Lactobacillus gasseri OLL2809株（MG2809）は，免 疫刺激活性を指標に選抜された乳酸菌である。また MG2809乳酸菌は, タブレット錠剤に加工されているた め, 持ち運び扔よび保存時の熱安定性に優れている。 こ れまで, MG2809乳酸菌による抗原特異的 IgE の抑制や スギ花粉抗原で誘発された好酸球増多に対する抑制 ${ }^{16,17)}$, 子宮内膜症患者のナチュラルキラー (natural killer: NK)
細胞活性の元進および月経痛症状の軽減が報告されてい る18)。また, 大学サッカー選手における 4 週間の MG2809 乳酸菌摂取によって一過性高強度運動後の NK細胞活性 の低下が抑制されることが報告されている19)。 しかし, MG2809乳酸菌の摂取が継続的な高強度運動に対する免 疫応答に及ぼす影響については不明である。

\section{目的}

そこで本研究では，大学ラグビー選手を対象とし， 9 週間のMG2809乳酸菌の摂取が唾液SIgA 分泌㧍よび感 冒症状に及ぼす影響について，プラセボ対照二重盲検並 行群間試験で検討した。

\section{方 法}

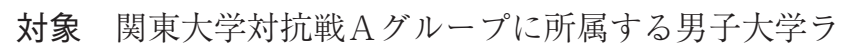
グビー選手 67 名（日本代表 5 名, ユニバーシアード日本 代表 1 名を含む）を対象とした，対象者は事前にスク リーニング検査として唾液SIgA 分泌速度の測定および 年齢，身長，体重の調查を実施した。研究内容を知らな い第 3 者によって, スクリーニング検査の結果を用い て, 対象者を, MG2809乳酸菌のタブレットを摂取する MG2809群（33名）およびプラセボタブレットを摂取す るプラセボ群（34名）に分けた（Table 1)。なお，全て の対象者に事前に実験の主旨や手順を説明し, 研究参加 の同意を得た，本研究は「ヘルシンキ宣言」の趣旨に従 い, 且つ「筑波大学体育系研究倫理委員会」の承認を得 て実施した（承認番号: 23-70号)。

MG2809乳酸菌 MG2809乳酸菌タブレット 1 錠には, $1 \times 10^{10}$ 個の熱処理されたLactobacillus gasseri OLL2809 株の乳酸菌が含まれている.MG2809乳酸菌タブレット およびプラセボタブレットは同形状の小瓶に入れて対象 者に配布した.タブレットの原材料は, 乳酸菌末(MG2809) あるいはプラセボ粉末（タンパク質㧍よび糖質）に，還 元麦芽糖水飴, 結晶セルロース, 安定剂 (CMC-Ca), 久

Table 1. Characteristics of subjects

\begin{tabular}{cccc}
\hline & $\begin{array}{c}\text { MG2809 } \\
(\mathrm{n}=33)\end{array}$ & $\begin{array}{c}\text { Placebo } \\
(\mathrm{n}=34)\end{array}$ & \\
\hline \hline age (year) & $20.0 \pm 0.2$ & $20.2 \pm 0.2$ & n.s \\
height (cm) & $176.4 \pm 1.1$ & $175.0 \pm 1.0$ & n.s \\
weight (kg) & $84.8 \pm 1.8$ & $85.3 \pm 1.9$ & n.s \\
\hline
\end{tabular}

All values are described as mean $\pm \mathrm{SE}$. n.s, non- significant. 
テアリン酸 $\mathrm{Ca}$, 微粒二酸化ケイ素が含有されている. 対 象者には，1日に2 錠（エネルギー1.9 kcal, タンパク 質 $0.050 \mathrm{~g}$, 脂質 $0.010 \mathrm{~g}$, 炭水化物 $0.41 \mathrm{~g}$, ナトリウム 0.75 mg) のタブレット（MG2809およびプラセボタブレット ともに同等）を，噛まずに水などと一緒に摂取するよう に指示した，摂取の時間帯は指定せず，対象者それぞれ のタイミングの良いときに摃取してもらった。

唾液の採取およびSIgAの定量方法 唾液採取は，乳酸 菌あるいはプラセボを摂取する前 (0 week), 摂取開始 2 週間後 $(2$ weeks $), 4$ 週間後 (4 weeks), 6 週間後 (6 weeks), 8 週間後 (8 weeks), 9 週間後 $(9$ weeks) の 合計 6 回行った (Fig. 1)。なお, 運動や食事による影響 を考慮し, 唾液の採取は起床後・朝食前・練習前の条件 が揃う午前 6 時から 7 時の間に行った。喠液の採取方法 について, 先行研究 20,21$)$ と同じ方法を用いた。ミミラル ウォーターで口腔内の洗浄 (30秒 $\times 3$ 回) を行った後に, 5 分間の座位安静をとり, サリベット（SALIVETTE, Sarstedt社製）を用いて脱脂綿を咀嚼（1秒間に 1 回の ペースで計60回）させ, 分泌された唾液を脱脂綿にしみ 込ませて採取した、垂液を含んだ脱脂綿は, 遠心分離 $(3,000$ rpm, $15 \mathrm{~min}$ )を行い, 得られた唾液の重量 $(\mathrm{g})$ を計量し, 測定に使用するまで-40ㄷ で保存した。唾液の比重を 1 として 1 分間あたりの唾液分泌量 $(\mu \mathrm{g} / \mathrm{min})$ を算出した。 SIgA 濃度は酵素免疫測定法 (Enzyme-linked immunosorbent assay: ELISA)を用いて測定した. SIgA濃度 $(\mu \mathrm{g} /$ $\mathrm{ml}$ ) 㧍よび唾液分泌量 ( $\mathrm{ml} / \mathrm{min}$ ) の積より SIgA 分泌速 度 $(\mu \mathrm{g} / \mathrm{min})$ を算出した。また, 各対象者のSIgA分泌 速度の值を 0 week のSIgA 分泌速度の值で除すること
によってSIgA 分泌速度の変化比を算出した。

感冒症状の調査 感冒症状の調査は, 赤間ら ${ }^{22)}$ の報告を 参考とし，調查用紙を用いて行った，対象者には毎日調 查用紙に感冒症状の有無を記載するように指示した，鼻 水, 咳, 咽喉痛, 痰, 熱感, 悪寒, 吐き気の 7 項目につ いて, 自覚症状の有無を調べ, 1 つ以上の症状が 3 日以 上続いた場合の発生件数を示した。

心理状態の調査 心理プロフィール検査 (profile of mood states shortened version: POMS 短縮版) を用い て, 緊張一不安, 抑うつ一落ち込み, 怒り一敵意, 活気, 疲労, 混乱の気分尺度を評価した ${ }^{23,24)}$ 。なお POMSは, 乳酸菌摂取前 (0 week), 摂取開始 4 週間後 (4 weeks), 9 週間後 (9 weeks) の合計 3 回測定した (Fig. 1). 実施 時刻は午前 6 時から 7 時の間であり, 唾液を採取する前 に記入するように指示した。

統計 各測定值は, 平均值士標準誤差で示した。各群に おける 0 week との比較にはWilcoxon signed-rank test を用いた，両群における感冒症状の出現者数㧍よび出現 回数, 出現日数の比較には Mann-Whitney testを用いた. 有意水準は $5 \%$ 未満とした。

\section{結 果}

唾液成分 唾液分泌量揖よびSIgA濃度, SIgA分泌速度 の変動を Table 2 に示した。唾液分泌量およびSIgA濃度, 唾液SIgA 分泌速度について, 両群とも乳酸菌摂取前 $(0$ week）と比べて有意な差はみられなかった. SIgA分泌

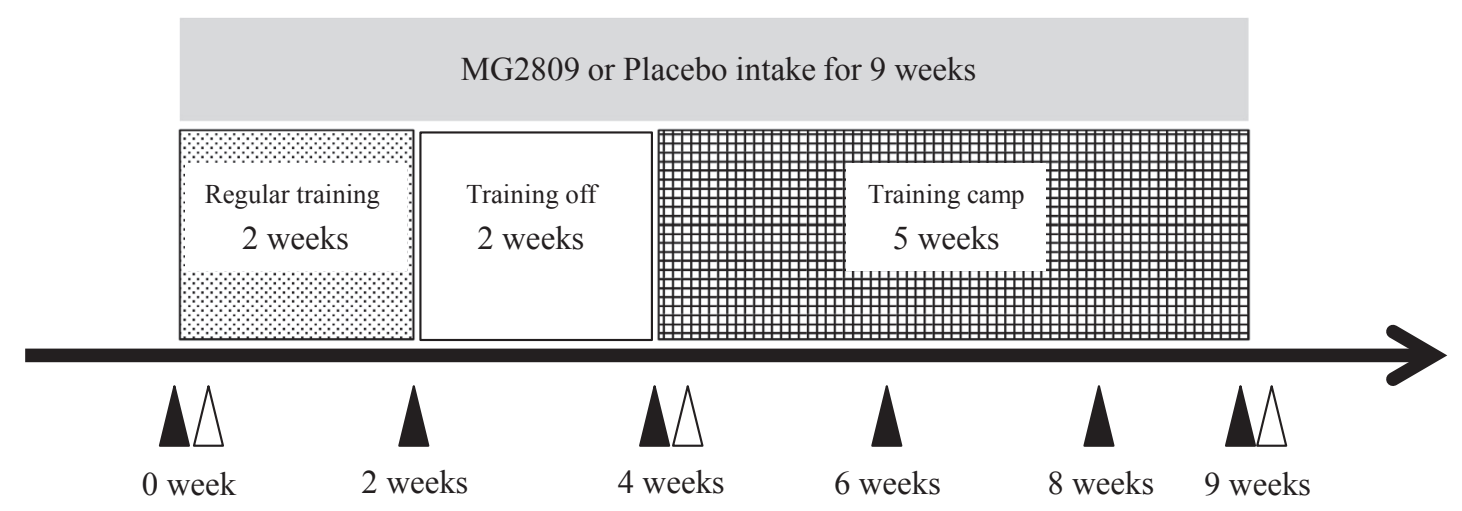

\section{$\Lambda \quad$ : Saliva $\triangle:$ :POMS}

Fig. 1 Protocol of the research.

This research was conducted for 9 weeks. Saliva samples were collected before (0 week) and after 2, 4, 6, 8, and 9 weeks of the MG2809 intakes. Profile of mood states (POMS) was measured at 0, 4, and 9 weeks. 
速度における変化比をFig. 2 に示した. MG2809群におい て, 乳酸菌摂取前 $(0$ week) と比べて摂取開始 6 週間後 $(6$ weeks）にSIgA 分泌の有意な上昇がみられた（ $<<0.05 ）$.

感冒症状 研究期間中に㧈いて感冒症状を訴えた選手 は, MG2809群で16名, プラセボ群で17名であった。 感 冒症状を訴えた選手の平均罹患回数は, MG2809群で 2.19 \pm 0.38 回 /人, プラセボ群で $1.97 \pm 0.40$ 回 /人であり, 両 群間に有意な差は認められなかった。感冒症状が 3 日以 上出現した選手に扮ける症状の出現日数を Fig. 3 に示し
た. MG2809群はプラセボ群と比べて感冒症状の出現日 数が有意に短かった $(\mathrm{p}<0.05)$.

心理状態 各POMSスコアの変動（緊張一不安, 抑うつ 一落ち込み, 怒り一敵意, 活気, 疲労, 混乱) をFig. 4 に示 した. MG2809群では, 活気が乳酸菌摂取前 (0 week) と比較して摂取開始 4 週間後 (4 weeks) および 9 週間 後 (9 weeks) に有意に高值を示し $(\mathrm{p}<0.05)$, 疲労が乳 酸菌摂取前 (0 week) と比較して摂取開始 4 週間後 (4 weeks）に有意に低い值を示した（p<0.05）。プラセボ

Table 2. Changes in salivary data

\begin{tabular}{ccccccc}
\hline & 0 week & 2 weeks & 4 weeks & 6 weeks & 8 weeks & 9 weeks \\
\hline saliva flow rate $(\mathrm{ml} / \mathrm{min})$ & & & & & & \\
MG2809 & $0.88 \pm 0.09$ & $0.96 \pm 0.09$ & $1.10 \pm 0.14$ & $0.97 \pm 0.09$ & $0.86 \pm 0.09$ & $0.89 \pm 0.08$ \\
Placebo & $1.12 \pm 0.10$ & $1.07 \pm 0.10$ & $1.12 \pm 0.09$ & $1.08 \pm 0.10$ & $0.95 \pm 0.09$ & $1.03 \pm 0.09$ \\
& & & & & & \\
SIgA concentration $(\mu \mathrm{g} / \mathrm{ml})$ & & & & & \\
MG2809 & $56.0 \pm 4.9$ & $54.2 \pm 4.6$ & $47.5 \pm 3.2$ & $57.1 \pm 4.7$ & $68.1 \pm 5.9$ & $62.7 \pm 7.5$ \\
Placebo & $49.0 \pm 3.9$ & $46.3 \pm 3.5$ & $47.0 \pm 3.3$ & $52.1 \pm 5.3$ & $55.2 \pm 3.9$ & $52.7 \pm 4.8$ \\
& & & & & & \\
SIgA secretion rate $(\mu \mathrm{g} / \mathrm{min})$ & & & & & & \\
MG2809 & $47.4 \pm 7.0$ & $52.8 \pm 6.7$ & $52.0 \pm 5.6$ & $55.6 \pm 6.7$ & $56.9 \pm 6.7$ & $56.6 \pm 7.6$ \\
Placebo & $50.9 \pm 4.8$ & $44.2 \pm 4.3$ & $51.6 \pm 5.2$ & $51.1 \pm 5.6$ & $49.9 \pm 5.6$ & $55.6 \pm 7.8$
\end{tabular}

All values are described as mean $\pm \mathrm{SE}$.

SIgA, Secretory Immunoglobulin A

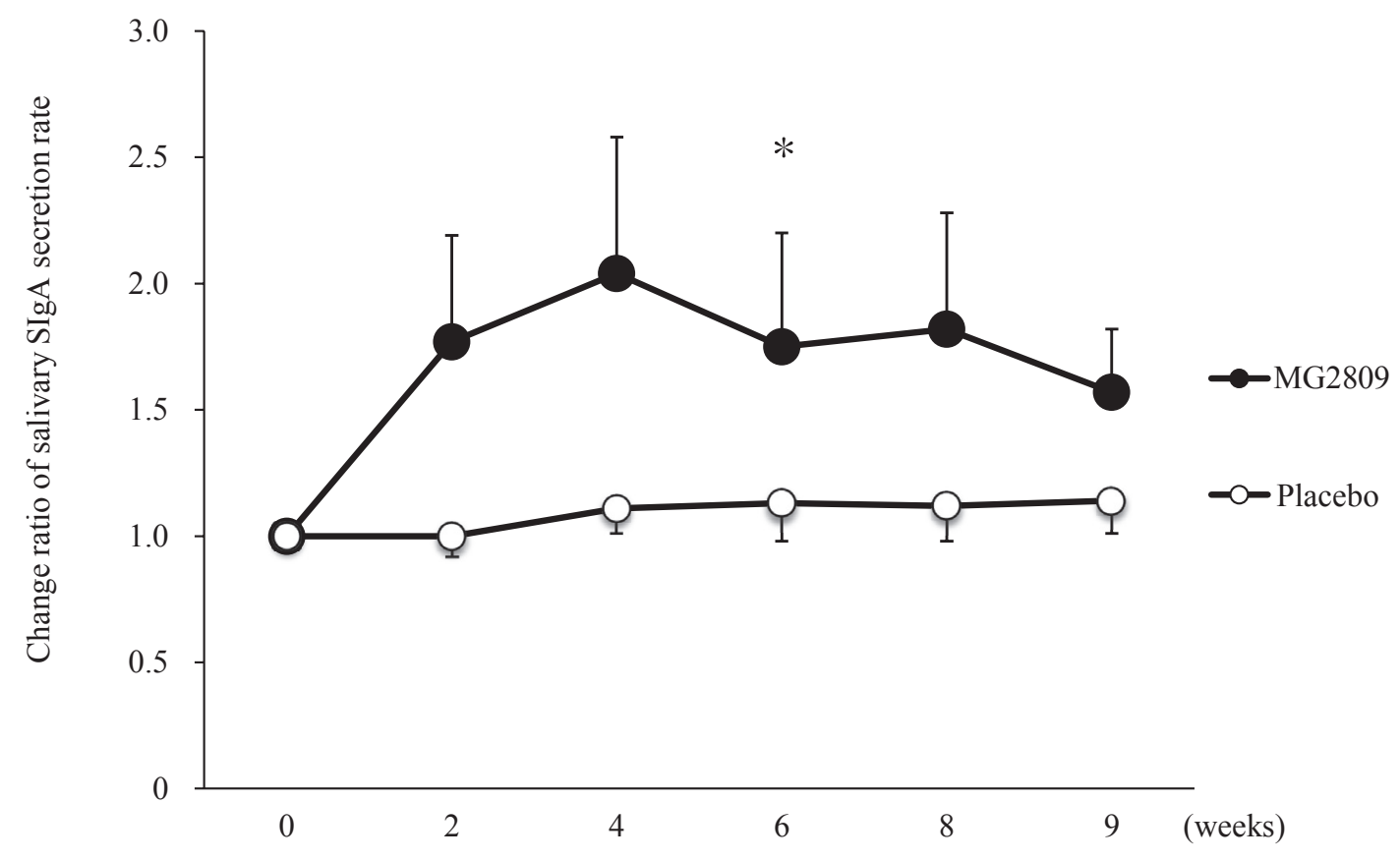

Fig. 2 Changes in salivary SIgA secretion rate during the study period.

- MG2809 intake group, $\bigcirc$ : Placebo intake group.

SIgA, Secretory Immunoglobulin A.

$*: \mathrm{P}<0.05$ vs. 0 week. 


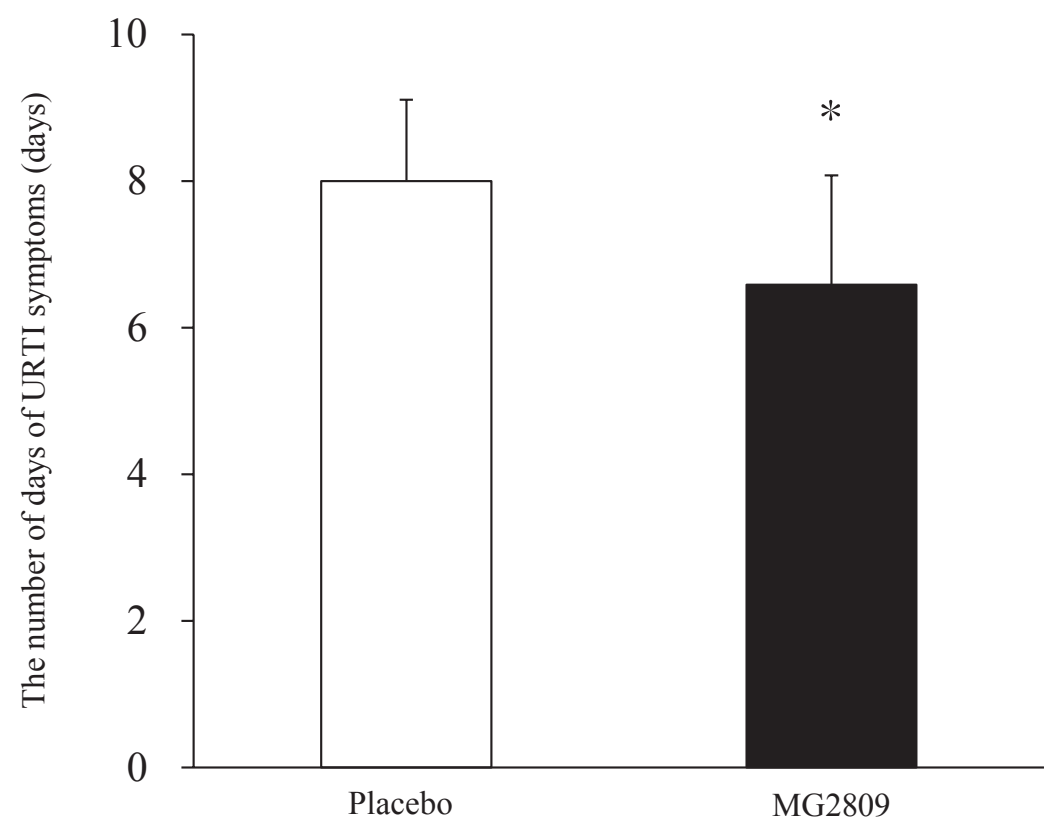

Fig. 3 Continuous days of URTI symptoms over three days during the study period. URTI, Upper respiratory tract infection. *: $\mathrm{P}<0.05$ vs. Placebo.

群では, 疲労が乳酸菌摂取前 (0 week) と比較して摂 取開始 4 週間後 (4 weeks) および 9 週間後 (9 weeks) に有意に低值を示した $(\mathrm{p}<0.05)$.

\section{考察}

本研究では, 大学ラグビー選手を対象とし， 9 週間の MG2809乳酸菌の摂取が唾液SIgA 掞よび感冒症状に及 ぼす影響について検討した。MG2809乳酸菌の摂取に より唾液SIgA 分泌は高まり, 感冒症状の出現日数が短 縮することが示された。従って, アスリートにおいて MG2809乳酸菌を摂取することは, 唾液SIgAによって 営まれる口腔内免疫能を高め, 感冒症状を軽快させる可 能性が示唆された。

唾液SIgA は口腔内免疫能の主体でありウイルスの粘 膜への侵入を防ぐ役割を持っている. 従って, SIgAを 高めることは感染防御の観点より非常に重要である。本 研究では, MG2809群に扔いて摂取前と比べて徐々に $\mathrm{SIgA}$ 分泌が高まった。 先行研究において, 継続的な乳 酸菌 (Lactobacillus plantarum ONRICb0240株) の摂 取が健康な高齢者や成人女性のSIgA 分泌を高めること が報告されている, ${ }^{9,10)}$ 。これらの先行研究と本研究で用 いた乳酸菌の株は異なるが, 同じLactobacillus 属であ る. 山平ら ${ }^{25)}$ は, 150 株の様々な乳酸菌を用いてマウス パイエル板細胞からの IgA 産生誘導能を検討したとこ ろ, Lactobacillus 属の乳酸菌の多くでIgA濃度が高まっ たことを報告している。本研究に抢いても，MG2809乳 酸菌がパイエル板においてB細胞を活性化させ, 唾液
SIgA 分泌の増加に繫がった可能性が考えられる，これ まで, SIgAの運動応答に対する乳酸菌の効果に関する メカニズムは明らかとなっていない. SIgAの分泌過程 は, IgA 産生 B 細胞から放出された二量体 IgAが, 粘膜 上皮細胞の基底膜側に発現する多量体免疫グロブリン受 容体 (polymeric immunoglobulin receptor: pIgR) に結 合し, 同上皮細胞内輸送過程で分泌成分として SIgAを 形成し，唾液腺導管を経て分泌されると考えられている. その分泌過程に扔いて、ヘルパーT細胞 1 （T-helper1: Th1）から放出されるインターフェロン (Interferon: IFN) - $\gamma$ が, B 細胞の IgA 産生 B 細胞への分化や, pIgR 合成を調節している ${ }^{26)}$. 高強度運動によって, 唾液SIgA 濃度の低下とともに唾液腺中の $\mathrm{pIgR}$ 発現の低下ゃ ${ }^{27,28)}$, 䫈下リンパ節中の Th細胞の減少が報告されており ${ }^{28)}$, 高強度運動によるこれらのSIgA 調節系の機能低下の可 能性が示されている. 本研究で用いたMG2809乳酸菌は, Th1 誘導サイトカインであるインターロイキン（Interleukin: IL) 12 産生を高, Th1による IFN- $\gamma$ の 産生立進に繫がった可能性がある。これらのことより， MG2809が経口摂取後に小腸上皮から生体内に取り込ま れ，マクロファージや樹状細胞がMG2809により活性化 し， IL-12を放出することでTh1細胞によるIFN- $\gamma$ 産 生を高め B 細胞の IgA 産生と $\mathrm{pIgR}$ の合成が促進させる ことで, 唾液中のSIgAが高まった可能性が推察される。

SIgA は, 継続的な高強度運動によって低下すること が知られている ${ }^{29,30)}$. 本研究では, MG2809群のSIgA分 泌は高まり,プラセボ群のSIgA 分泌は変動しなかった。 
(a) Tension- Anxiety

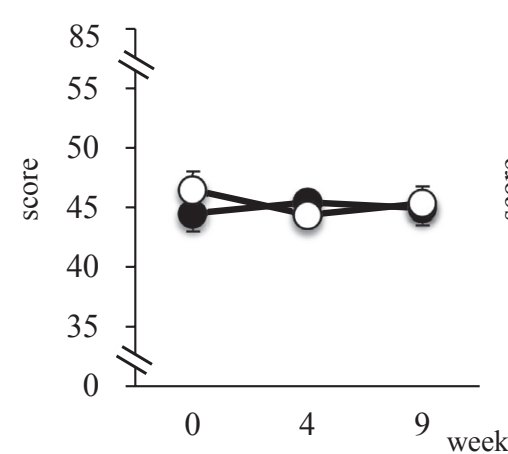

(b) Depression-Dejection

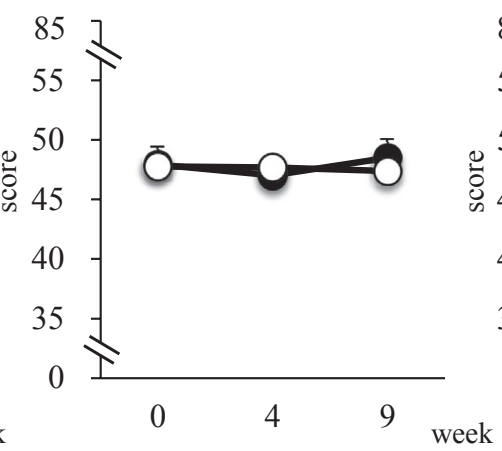

(c) Anger-Hostility

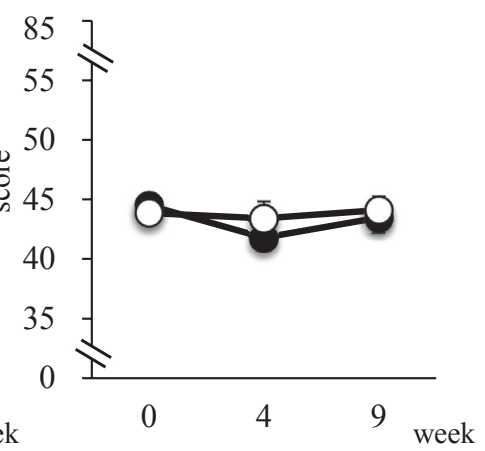

(d) Vigor

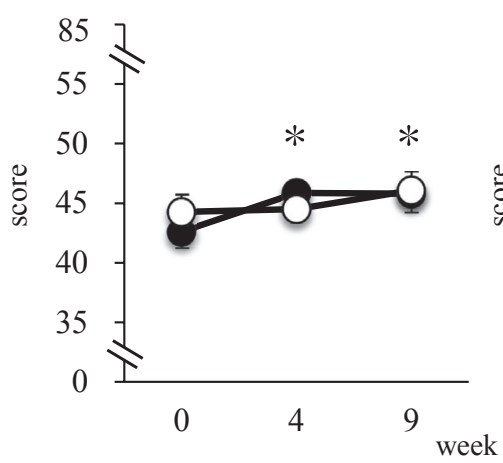

(e) Fatigue

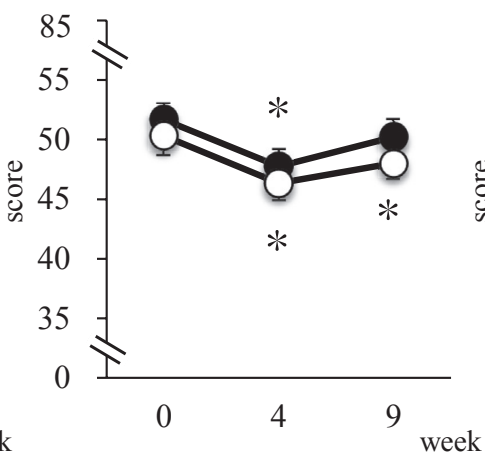

(f) Confusion

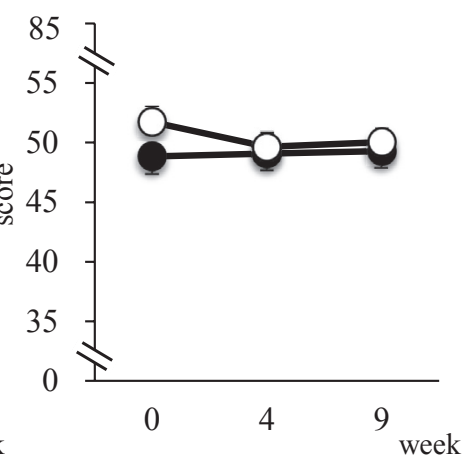

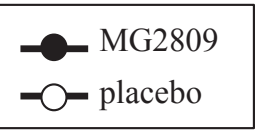

Fig. 4 Changes in POMS score such as Tension-Anxiety (a), Depression-Dejection (b), Anger-Hostility (c), Vigor (d), Fatigue (e), and Confusion (f) during the study period.

*: $\mathrm{P}<0.05$ vs. 0 week.

先行研究に扔いて, 山内ら ${ }^{29)}$ はラグビー選手を対象に 5 週間の合宿で安静時の唾液中 SIgA分泌が低下すること を報告している。ささらに秋本ら ${ }^{30}$ は, 剣道選手を対象に 10 日間の寒稽古で安静時のSIgA分泌が低下し, 合宿終 了10日後に执いてもSIgAが回復しなかったことを報告 している。本研究は, 通常練習期よりスタートし 2 週間 の全体練習オフの後，5週間の強化合宿を実施した。プ ラセボ群における唾液SIgAが変動しなかった理由とし て, 乳酸菌摂取前 (0 week) に扔ける唾液SIgAレベル が元々低かった可能性が考えられる。本研究の対象は, 関東大学対抗戦㧍よび全国大学選手権の優勝圈内にある チームであり, 測定を実施した年は例年に比べ通常練習 期の練習量が多い状況であった。 また, 全体練習はオ フであったが個人練習は実施されたことが，オフ後 $(4$ week)にSIgAが回復しなかった理由として考えられる。 実際に, POMSの疲労項目が乳酸菌摂取前 (0 week) で 最も高值を示しており, 通常練習期に扔ける疲労が高
かったことが考えられる.また, 強化合宿に扔いて最後 の 1 週間は主に試合形式の練習が実施され，これまでの メニューに比べると運動量や強度は低かった。このこと も疲労項目や唾液 SIgAに影響した可能性が考えられる。 しかし, 本研究ではトレーニング量を調査していないこ とや主観的指標を頻繁に測定していないため, 今後はこ れらの指標を把握した上で乳酸菌が口腔内免疫能に及ぼ す効果について詳細に検討する必要があると考える。い ずれにせよ, MG2809群においては乳酸菌摂取開始 6 週 間後（6 weeks）でSIgA 分泌が高まった。高強度運動 により, 口腔内免疫能が低下しやすい期間に抒いて, 乳 酸菌の摂取による唾液SIgAの无進が認められたことは, コンディショニングの観点に打いて有益な情報である.

先行研究より, 乳酸菌の継続的な摂取によって感冒症 状の継続日数が短縮されることや ${ }^{10)}$, 感冒症状を軽減さ せることが報告されている9 ${ }^{9}$ ，本研究に扔いて，感冒症 状の出現者数㧍よび出現回数について両群に差はみられ 
なかったが，MG2809群はプラセボ群と比較して感冒罹 患の出現日数が短いことから, 継続的な乳酸菌の摂取が 感冒症状の出現日数を短縮させる可能性が考えられた。 インフルエンザウイルスやライノウイルス等の上気道感 染症を招くウイルスは, 粘膜上皮側から上皮細胞に侵入 し, 感染後に複製されたウイルスは, 上皮細胞から粘膜 上皮側へ出芽し, 再び粘膜上皮側から侵入して感染が 広がるといった仕組みとなっている ${ }^{31}$ 。 これらのことよ り, MG2809群においては乳酸菌の摂取によって増加し たSIgAが, 複製されたウイルスの再侵入の抑制や毒素 の中和に作用することで感染の拡大を抑え, 感冒の出現 日数の短縮に貢献した可能性が考えられた。また先行研 究において, 乳酸菌がヒトの血中 IFN- $\gamma$ レベルやマウ ス由来細胞に打ける IL-12, 掞よびIFN- $\gamma$ 産生を高め ることが報告されている ${ }^{12,32)}$. 前述したようにIL-12 は, $\mathrm{Th} 1$ 細胞の IFN- $\gamma$ 産生を活性化させ, SIgA 産生の充進 に貢献する ${ }^{26)}$. さらにIL-12 はNK細胞の活性化を誘導 することが知られている.MG2809乳酸菌の摂取がヒ トの NK 細胞活性を高めることも報告されている ${ }^{18,19)}$. 従って, MG2809乳酸菌がSIgAの分泌促進だけでなく, IL-12を介したTh細胞やNK細胞などの全身免疫系の克 進に影響を及ぼし, 感冒症状の出現日数が短縮した可能 性も考えられる，今後は全身免疫系の運動応答に対する MG2809の効果も合わせて検討する必要がある.

先行研究に拈いて，MG2809がストレスホルモンや心 理的ストレスに影響を及ぼすことが報告されている ${ }^{19.33)}$. MG2809を投与したラットで浸水ストレス負荷試験を 行ったところ，血中コルチコステロンの増加を抑制する ことが報告されている33). また MG2809の摂取によって, 不安や緊張といった心理的ストレスを軽減させたことが 報告されている ${ }^{18)}$ 。本研究では, MG2809群において乳 酸菌摂取開始 6 週間後 (6 weeks) に活気が有意に高値を 示した. 先行研究において, 乳酸菌発酵茶葉飲料 (Lactobacillus brevis mh4219株) の摂取が, 算術ストレス負荷 後の活気の低下を抑制させることが報告されている ${ }^{34)}$. MG2809乳酸菌の摂取は, 日常的に身体的および心理的 ストレスが負荷されるアスリートに执いて，良好なコン デイションの維持に有効となる可能性が示唆された.

\section{結 語}

本研究では, 大学ラグビー選手を対象にMG2809乳酸 菌の継続的な摄取が唾液 SIgA と感冒症状に及ぼす効果 について調べた。その結果, MG2809乳酸菌の摂取によ り唾液SIgA 分泌の高まりと, 感冒症状の継続日数の短 縮が認められた。また，MG2809乳酸菌の摂取により POMSテストに扔いて活気が上昇した，以上のことより， MG2809乳酸菌の摂取は, 口腔内免疫能の立進および感 冒症状の軽減や心理面において好影響を及ぼすことが明
らかとなり，アスリートに扔ける良好なコンデイション の維持に有効となる可能性が示唆された.

\section{利益相反について}

本研究は, 株式会社明治食機能科学研究所乳酸菌研究部 の田村 明が共著者となっている.

\section{引用文献}

1) Engebretsen L, Soligard T, Steffen K, Alonso JM, Aubry M, Budgett R, Dvorak J, Jegathesan M, Meeuwisse WH, Mountjoy M, Palmer-Green D, Vanhegan I, Renström PA. Sports injuries and illnesses during the London Summer Olympic Games 2012. Br J Sports Med 47: 407-414, 2013.

2) Mackinnon LT, Chick TW, van As A, Tomasi TB. The effect of exercise on secretory and natural immunity. Adv Exp Med Biol 216: 869-876, 1987.

3）秋本崇之, 赤間高雄, 杉浦弘一, 龍野美恵子, 香田泰子, 和久貴洋, 河野一郎：持久性ランニングによる口腔局所 免疫能の変動, 体力科学, 47: 53-62, 1998.

4) Fahlman MM, Engels HJ. Mucosal IgA and URTI is American college football players: a year longitudinal study. Med Sci Sports Exerc 37: 374-380, 2005.

5) Gleeson M, McDonald WA, Pyne DB, Cripps AW, Francis JL, Fricker PA, Clancy RL. Salivary IgA levels and infection risk in elite swimmers. Med Sci Sports Exerc 31: 67-73, 1999.

6) Neville V, Gleeson M, Folland JP. Salivary IgA as a risk factor for upper respiratory infections in elite professional athletes. Med Sci Sports Exerc 40: 1228-1236, 2008.

7) de Vrese M, Winkler P, Rautenberg P, Harder T, Noah C, Laue C, Ott S, Hampe J, Schreiber S, Heller K, Schrezenmeir J. Probiotic bacteria reduced duration and severity but not the incidence of common cold episodes in a double blind, randomized, controlled trial. Vaccine 10: 6670-6674, 2006.

8) Hatakka K, Savilahti E, Pönkä A, Meurman JH, Poussa T, Näse L, Saxelin M, Korpela R. Effect of long term consumption of probiotic milk on infections in children attending day care centres: double blind, randomised trial. BMI (clinical research ed.) 322: 1-5, 2001.

9) Kotani Y, Shinkai S, Okamatsu H, Toba M, Ogawa K, Yoshida H, Fukaya T, Fujiwara Y, Chaves PH, Kakumoto K, Kohda N. Oral intake of Lactobacillus pentosus strain b240 accelerates salivary immunoglobulin A secretion in the elderly: A randomized, placebocontrolled, double-blind trial. Immunity \& ageing 7: $1-11,2010$.

10）岸和正, 小谷吉史, 山平聡子, 戸羽正道, 岡松 洋, 三原修 一, 鶴田容子, 竹原美沙, 赤星亜朱香, 南 久則 : Lactobacillus plantarum ONRICb0240 は健常成人の唾液 IgA量 を高める, 日本乳酸菌学会誌, 17: 132-137, 2006.

11) Shimizu K, Sato H, Suga $Y$, Yamahira S, Toba M, Hamuro K, Kakumoto K, Kohda N, Akama T, Kono I, 
Kuno S. The effects of Lactobacillus pentosus strain b240 and appropriate physical training on salivary secretory IgA levels in elderly adults with low physical fitness: a randomized, double-blind, placebo-controlled trial. J Clin Biochem Nutr 54: 61-66, 2013.

12) Cox AJ, Pyne DB, Saunders PU, Fricker PA. Oral administration of the probiotic Lactobacillus fermentum VRI-003 and mucosal immunity in enduranceathletes. Br J Sports Med 44: 222-226, 2010.

13) Weber-Mzell D, Kotanko P, Hauer AC, Goriup U, Haas J, Lanner N, Erwa W, Ahmaida IA, Haitchi-Petnehazy S, Stenzel M, Lanzer G, Deutsch J. Gender, age and seasonal effects on IgA deficiency: a study of 7293 Caucasians. Eur J Clin Invest 34: 224-228, 2004.

14) Gleeson M, Bishop NC, Oliveira M, Tauler P. Daily Probiotic's (Lactobacillus casei Shirota) reduction of infection incidence in athletes. Int J Sport nutr Metab 21: 55-64, 2011.

15) Shimizu K, Suzuki N, Nakamura M, Aizawa K, Imai T, Suzuki S, Eda N, Hanaoka Y, Nakao K, Suzuki N, Mesaki N, Kono I, Akama T. Mucosal immune function comparison between amenorrheic and eumenorrheic distance runners. J Strength Cond Res 26: 1402-1406, 2012.

16) Gotoh M, Sashihara T, Ikegami S, Yamaji T, Kino K, Orii N, Taketomo N, Okubo K. Efficacy of oral administration of a heat-killed Lactobacillus gasseri OLL2809 on patients of Japanese-cedar pollen-specific IgE. Biosci Biotechnol Biochem 73: 1971-1977, 2009.

17) Sashihara T, Ikegami S, Sueki N, Yamaji T, Kino K, Taketomo N, Gotoh M, Okubo K. Oral administration of heat-killed Lactobacillus gasseri OLL2809 reduces cedar pollen antigen-induced peritioneal eosinophilia in Mice. Allergology International 57: 397-403, 2008.

18) Itoh $H$, Uchida M, Sashihara T, Ji ZS, Li J, Tang Q, Ni S, Song L, Kaminogawa S. Lactobacillus gasseri OLL2809 is effective especially on the menstrual pain and dysmenorrhea in endometriosis patients: randomized, double-blind, placebo-controlled study. Cytotechnology 63: 153-161, 2011.

19) Sashihara T, Nagata M, Mori T, Ikegami S, Gotoh M, Okubo K, Uchida M, Itoh H. Effects of Lactobacillus gasseri OLL2809 and $\alpha$-lactalbumin on universitystudent athletes: a randomized, double-blind, placebocontrolled clinical trial. Appl Physiol Nutr Metab 38: 1228-1235, 2013.

20) Shimizu K, Suzuki N, Nakamura M, Aizawa K, Imai T, Suzuki S, Eda N, Hanaoka Y, Nakao K, Suzuki N, Mesaki N, Kono I, Akama T. Mucosal immune function comparison between amenorrheic and eumenorrheic distance runners. J Strength Cond Res 26: 1402-1406, 2012.

21) Akimoto T, Nakahori C, Aizawa K, Kimura F, Fukubayashi T, Kono I. Acupuncture and responses of immunologic and endocrine markers during competition. Med Sci Sports Exerc 35: 1296-1302, 2003.
22）赤間高雄, 和久貴洋, 和久美紀, 杉浦弘一, 秋本崇之, 龍 野美恵子, 香田泰子：感染症アンケートの実施及び集計 について, 平成 7 年度日本体育協会スポーツ医・科学研 究報告 No.IX スポーツ活動が免疫に与える影響に関す る研究 一第 2 報一: 19-24, 1995.

23) Douglas M, McNair, Maurice Lorr, Leo F. Profile of Mood States, San Diego, Educational and Industrial Testing Service, 1971.

24）横山和仁：POMS（感情プロフィール検査）日本語版 の作成と信頼性および妥当性の検討, 日本公衛誌, 37: 913-918, 1990.

25）山平聡子, 戸羽正道, 岸 和正, 岡松 洋 : 粘膜免疫を刺激 する発酵茶由来の乳酸菌, 日本乳酸菌学会誌, 17: 57-60, 2006.

26) Loman S, Jansen HM, Out TA, Lutter R. Interleukin-4 and interferon-gamma synergistically increase secretory component gene expression, but are additive in stimulating secretory immunoglobulin A release by Calu-3 airway epithelial cells. Immunology 96: 537543, 1999.

27) Kimura F, Aizawa K, Tanabe K, Shimizu K, Kon M, Lee H, Akimoto T, Akama T, Kono I. A rat model of saliva secretory immunoglobulin: a suppression caused by intense exercise. Scand J Med Sic Sports 18: 367372, 2008.

28) Boudreau J, Quadrilatero J, Hoffman-Goetz L. Voluntary training in mice and submandibular lymphocyte response to acute exercise. Med Sic Sports Exerc 37: 2038-2045, 2005.

29）山内亮平, 清水和弘, 古川拓生, 渡部厚一, 竹村雅裕, 赤 間高雄, 秋本崇之, 河野一郎：大学ラグビー選手におけ る合宿期間中の唾液中分泌型免疫グロブリン Aの变動, 体力科学, 58: 131-142, 2009.

30）秋本崇之, 赤間高雄, 香田泰子, 和久貴洋, 林 栄輔, 龍野 美恵子, 杉浦弘一, 天野和彦, 河野一郎：高強度卜レー二 ングによる安静時唾液中分泌型 IgAの変動, 体力科学, 47: 245-252, 1998.

31）水見徹夫, 高野賢一, 大國 毅, 小笠原徳子, 正木智之, 小 幡和史, 堤 裕幸, 小島 隆, 澤田典均, 横田伸一：ウイル 又性上気道炎での免疫応答と鼻粘膜上皮の役割, 耳鼻咽 喉科展望, 56: 162-177, 2013.

32) Shida K, Makino K, Morishita A, Takamizawa K, Hachimura S, Ametani A, Sato T, Kumagai Y, Habu S, Kaminogawa S. Lactobacillus casei inhibits antigeninduced $\operatorname{IgE}$ secretion through regulation of cytokine production in murine splenocyte cultures. Int Arch Allergy Immunol 115: 278-287, 1998.

33) Itoh H, Sashihara T, Hosono A, Kaminogawa S, Uchida M. Lactobacillus gasseri OLL2809 inhibits development of ectopic endometrial cell in peritoneal cavity via activation of NK cells in a murine endometriosis model. Cytotechnology 63: 205-210, 2011.

34）森 久子, 渡部恭子, 磯野義員 : 茶抽出物中で $\gamma$ アミノ 酪酸を生成する乳酸菌Lactobacillus brevis mh4219の 分離とそれを用いた発酵茶飲料のストレス軽減効果, 生 物工学会誌, 85: 521-526, 2007. 